\title{
Experimental Study on Porous Current Collectors of PEM Electrolyzers
}

Hiroshi Ito a*, Tetsuhiko Maeda a, Akihiro Nakano a, Chul Min Hwang b, Masayoshi Ishida ${ }^{b}$, Atsushi Kato ${ }^{c}$, Tetsuya Yoshida d

a: Energy Technology Research Institute, National Institute of Advanced Industrial

Science and Technology (AIST), 1-2-1 Namiki, Tsukuba 305-8564, Japan

b: Department of Engineering Mechanics and Energy, University of Tsukuba, 1-1-1

Tennoudai, Tsukuba 305-8573, Japan

c: Takasago Thermal Engineering Co., Ltd., 3150 Iiyama, Atsugi 243-0213, Japan

d: Daiki Ataka Engineering Co., Ltd., 11 Shintoyofuta, Kashiwa 277-8515, Japan

*Corresponding author, E-mail: ito.h@aist.go.jp

Tel: +81-29-861-7262, Fax: +81-29-851-7523

\begin{abstract}
Experimental study on proton exchange membrane (PEM) electrolyzer was carried out focusing on the effect of pore structural properties of current collectors, such as porosity and pore diameter. Various titanium (Ti)-felt substrates with different porosities and
\end{abstract}


pore diameters (measured by capillary flow porometry) were used as the anode current collector. Results show that when the mean pore diameter of the current collector was larger than $10 \mu \mathrm{m}$, the electrolysis performance improved with decreasing pore diameter. In contrast, changes in porosity had no significant effect on the cell performance when the porosity exceeded 0.50 . The flow pattern of two-phase flow in the flow channel was discussed in terms of its relationship to bubble size and to pore diameter of the current collector. Finally, correlation between the calculated membrane resistance and the measured pore diameter of the current collectors suggest that larger bubbles generated from larger pores tend to become long bubbles in the channel, thus hindering the water supply to the membrane.

Key words: PEM electrolysis, current collector, pore diameter, proton conductivity 


\section{Introduction}

Hydrogen production linked to renewable sources is a critical process for establishing a "hydrogen society" with zero environmental impact. The integration of renewables (hydro, wind, photovoltaic) with water electrolysis is an attractive option to achieve such a society $[1,2]$. A proton exchange membrane (PEM) water electrolyzer has recently attracted attention because of its wide range of current density and high conversion efficiency [3-6].

The configuration of a PEM electrolyzer is similar to that of a PEM fuel cell (PEMFC) in that it consists of a membrane electrode assembly (MEA), current collectors, bipolar plates with flow channels, bus plates, manifolds, and end plates. The current collector is a porous medium placed between the MEA and bipolar plate at both electrode sides. The two major roles of a current collector are similar to those of gas diffusion layers (GDLs) of a PEMFC, namely, electric conduction between the electrode and the bipolar plate and efficient gas transport from the electrode to the flow channels. In a typical PEMFC, carbon paper or carbon cloth is used as the GDL at both sides of the electrodes. However, in a PEM electrolyzer, carbon material cannot be used for either the oxygen electrode (anode) or for the GDL (i.e., current collector), because the potential of the anode during electrolysis operation is so cathodic that carbon material 
tends to corrode. Thus, in a PEM electrolyzer, the anode current collector is typically titanium $(\mathrm{Ti})$ in the form of sintered porous media, expanded screen mesh, or felt (unwoven fabric).

At the anode of a PEM electrolyzer, liquid water is transferred through the current collector from the flow channel and dissociated into molecular oxygen. Produced oxygen gas diffuses back to the flow channel by diffusion through the anode current collector. Liquid water acts as a reactant in the anode reaction while simultaneously humidifying the membrane to maintain high proton conductivity. If the produced oxygen cannot be removed efficiently, the anode channel will be blocked, thus limiting the mass transport. Therefore, efficient mass transport of liquid (water) and gas (oxygen) through the anode current collector is crucial for stable operation of a PEM electrolyzer. Despite its importance, however, correlation between electrolysis performance and the properties of the current collector such as porosity, pore size, and hydrophobicity, has not been extensively studied. Grigoriev et al. [7] presented an optimization of the current collector from the view point of mass transport. Based on their experimental data using a porous plate of sintered Ti-powder, they determined that the optimum pore size of a current collector is $12-13 \mu \mathrm{m}$. However, a definitive correlation between cell performance and pore size has not yet been clearly presented. 
Hwang et al. [8] carried out electrolysis experiments using unitized reversible fuel cells (URFCs) with different Ti-felt current collectors, and concluded that when the mean pore diameter (MPD) of a porous current collector is smaller than about $60 \mu \mathrm{m}$, electrolysis performance is not noticeably affected by changes in either the polytetrafluoroethylene (PTFE) content or porosity, whereas when the MPD $>100 \mu \mathrm{m}$, cell performance is degraded at a high current density $\left(>0.5 \mathrm{~A} / \mathrm{cm}^{2}\right)$. In a previous study [9], we focused on the flow pattern of two-phase flow in the flow channel and investigated the relation of flow pattern and electrolysis performance.

At the cathode, hydrogen gas is produced and diffuses through the current collector to the flow channel. Contrary to the anode reaction, the cathode reaction does not require liquid water, although liquid water is transferred (by electro-osmosis) from the anode and is accompanied by protons in the membrane. Thus, hydrogen gas and liquid water are simultaneously transported to the channel through the current collector during electrolysis operation. Because the activation overpotential of the cathode reaction is small $[10,11]$, the effect of the properties of the cathode current collector on the cell performance is limited.

Similar to the anode of a PEM electrolyzer, the anode of a direct methanol fuel cell (DMFC) has simultaneous mass transport of the supply of liquid reactant and the 
release of gas product through the porous media. In a DMFC where carbon paper or carbon cloth is used as the GDL the same as in a PEMFC, carbon dioxide $\left(\mathrm{CO}_{2}\right)$ generated at the anode diffuses through the GDL and flows into the channel flow of methanol. The two-phase flow of methanol and $\mathrm{CO}_{2}$ gas in the anode channel has been visualized using a transparent DMFC [12-20]. Argyropoulos et al. [12,13] noted that carbon paper is not suitable as a GDL of a DMFC due to its poor gas removal properties, whereas carbon cloth has relatively good gas removal properties. Lu and Wang [15] also concluded that carbon cloth is more suitable than carbon paper for GDL and that $\mathrm{CO}_{2}$ bubbles produced by hydrophilic carbon cloth are more uniform and smaller than those produced by hydrophobic carbon cloth. These flow visualization studies on DMFC generally revealed that the minimum bubble size is comparable to the size (i.e., width or depth) of the channel $(\sim 1 \mathrm{~mm})$ and thus, dispersed bubbly flow is rarely observed and the presence of slug flow in the channel leads to a smaller effective mass transport area between methanol and the GDL and to degradation in cell performance.

In this work, the effect of pore structural properties (i.e., porosity and pore diameter) of the anode current collector on the performance of a PEM electrolyzer was investigated experimentally. Various Ti-felt substrates with different porosities and pore diameters (measured by capillary flow porometry) were used as the anode current 
collector in a PEM electrolyzer. Electrolysis performance was measured for each cell set-up. Results revealed that the measured pore diameter of the current collector was correlated with cell performance and with ohmic resistance of the cell.

\section{Experimental}

\subsection{PEM electrolysis}

The experimental set-up of the PEM electrolyzer and the balance of plant (BOP) used in this present study has been described previously [9]. This electrolyzer was a small single cell $\left(27 \mathrm{~cm}^{2}\right)$ that had the commonly used PEMFC configuration, consisting of a membrane electrode assembly (MEA), porous current collectors, and separators (bipolar plates) with flow channels. The MEA used here was designed for a URFC and was developed by Takasago Thermal Engineering Co. and Daiki Ataka Engineering Co. For the MEA fabrication, catalytic electrodes were hot pressed to both surfaces of the membrane (Nafion 115). An iridium oxide $\left(\mathrm{IrO}_{2}\right)$ and platinum $(\mathrm{Pt})$ mixed electrocatalyst was used for the oxygen electrode, and a Pt catalyst was used for the hydrogen electrode. Carbon paper (Toray TGP-H-090) with a porosity of 0.78 was used for the current collector of the cathode. Table 1 summarizes the types of Ti-felt prepared and used as the current collectors. First, three types of Ti-felt of different fiber diameter 
$(\phi)$ and porosity $(\varepsilon)$ were prepared, in which A1 and A3 had the same $\phi(20 \mu \mathrm{m})$ and A1 and A2 had the same $\varepsilon(0.75)$. Then, to change their pore structure ( $\phi$ and $\varepsilon)$, three substrates (B1-B3) were prepared by loading Ti-powder (20 $\mu \mathrm{m}$ average diameter) onto bare substrates of A1-A3. The Ti-powder loading process was similar to conventional carbon-powder MPL loading for GDL of a PEMFC, that is, a slurry containing PTFE, Ti-powder, distilled water and a surface active agent was prepared by mixing with an impeller blade-type mixer, and then spread onto the substrate using a bar coating machine. (The wt\% ratio of Ti-powder and PTFE binder in the slurries was 99 to 1.) The $\mathrm{B} 1, \mathrm{~B} 2$, and $\mathrm{B} 3$ substrates were then dried at $180^{\circ} \mathrm{C}$ for $30 \mathrm{~min}$ to evaporate the remaining solvent, and finally sintered at $360^{\circ} \mathrm{C}$ in vacuum condition for 1 hour. In the cell set-up, the flow field of the bipolar plates at both sides was 26 channels in parallel and each channel had a square cross-sectional area of $0.01 \mathrm{~cm}^{2}$ [9].

The cell temperature was controlled by a thermocouple inserted in the body of the cell and by electric heaters on the cover plates of the cell. De-ionized liquid water was circulated by an accumulator, pump, preheating tank, flow meter, and flow control valve. Theoretically, water must be supplied only to the oxygen electrode side, because water molecules move along with protons to the hydrogen electrode during electrolysis. In the present experiments, however, water was circulated at a flow rate of $25 \mathrm{ml} / \mathrm{min}$ at 
both sides of the electrodes to prevent membrane burn־out caused by lack of water. Two-phase flow of gas and liquid was released from the exit of the cell at both electrodes, and the produced gas $\left(\mathrm{H}_{2}\right.$ and $\left.\mathrm{O}_{2}\right)$ was separated from liquid water at the respective accumulators. DC power for the electrolysis was supplied and controlled by a power supply (PAN16, Kikusui). Finally, the cell voltage (V) was measured at each current density (i) during PEM electrolysis for each cell set-up. In addition, the present PEM electrolyzer could be also operated as a PEMFC, because the MEA was customized for a URFC. In the FC experiments using these cells, the cell ohmic resistance was observed in situ using the AC impedance method as previously described [8].

\subsection{Capillary flow porometry}

The pore diameter of the porous current collectors was measured using capillary flow porometry (CFP) as an ex-situ measurement as follows [21-23]. A sample of the porous media was soaked in a liquid that spontaneously fills the pores. Dry gas at a given flow rate was then introduced into the prewetted substrate. Removal of the wetting liquid from the pores was not spontaneous, however. The equilibrium relationship between the surface tension of the liquid (i.e., capillary pressure) and air pressure (Fig. 1A) was used to calculate the pore diameter $\left(d_{\mathrm{p}}\right)$ : 


$$
d_{\mathrm{p}}=\frac{4 B \gamma \cos \theta}{P}
$$

where $B$ is the capillary constant, $\gamma$ is surface tension, $\theta$ is contact angle, and $P$ is applied gas pressure. The capillary constant is a tortuosity factor and set at 0.715 in the present measurement as the same as the American Society for Testing Material Committee (ASTM) [21]. When the wetting liquid has very low of $\gamma$ and $\theta$, then $\cos \theta \approx 1$. Based on Eq. (1), the lowest pressure of gas flowing is required to empty the largest pore. Therefore, there would be no gas flow through the substrate containing liquid-filled pores, and the gas begins to flow when the pressure is increased to a value sufficient to empty the largest pore. This breakthrough point is considered the bubble point. Further increase in gas pressure would empty the smaller pores and increase the gas flow rate, according to the wet flow curve (Fig. 1B). Here, the dry flow curve was obtained using a completely dry substrate, and the half-dry flow curve was calculated from the dry curve and was half of the flow rate through the dry sample at any given pressure (Fig 1B). The maximum $d_{\mathrm{p}}$ obtained from the gas pressure of the bubble point and Eq. 1 is called the bubble point diameter (BPD), and the gas pressure at the intersection of the half-dry flow and wet flow is the mean pore diameter (MPD).

In this study, the BPD and MPD of the Ti-felt substrates used for the anode current collectors were measured using the CFP apparatus (Model 1200AEL, PMI) and 
the above described procedure. An agent (Fluorinert, 3M) with a low surface tension $\left(=16 \mathrm{mNm}^{-1}\right)$ was used for the wetting liquid. Dry air flowed through the substrate in the though-plane direction. Table 1 lists the measured BPD and MPD.

\section{Results and discussion}

\subsection{Polarization characteristics of electrolysis}

Figures $2 \mathrm{~A}$ and $2 \mathrm{~B}$ show the measured $i-V$ characteristics during PEM electrolysis with different anode current collectors: bare Ti-felt (A1, A2 and A3) and Ti-powder loaded Ti-felt at $0.20 \mathrm{~g} / \mathrm{cm}^{3}$ (B1-2, B2 and B3). Although an MEA customized for a URFC was used here, the cell performance during electrolysis was fairly good. For all the collectors studied here, changes in $\varepsilon$ (A1 and A3 in Fig. 2A, and B1-2 and B3 in Fig. 2B) had no significant effect on the cell performance. However, V of A2 (Fig. 2A) and B2 (Fig. 2B) was significantly higher than that for the other collectors, about 25-30 mV at around $1.0 \mathrm{~A} / \mathrm{cm}^{2}$, and was beyond the range of experimental reproducibility $( \pm 5 \mathrm{mV})$. In the B1 series (B1-1 - B1-3) and in B2, previously reported SEM images of the Ti-felt substrate revealed that the loaded Ti-powder did not form a layer covering the substrate but instead intruded into the bulk of the substrate [24,25]. Therefore, in the present study, Ti-powders were relatively uniformly distributed not only in the in-plane 
direction but also in the through-plane direction of the current collectors of the B1 series and of B2. Even though the loading procedure for the Ti-powder was similar to that for MPL for the GDL of PEMFC, the density of Ti powder was relatively high compared to the viscosity of the slurry and $d_{\mathrm{p}}$ of the bare Ti-felt substrates of A1 and A2 was larger than the powder diameter $(\sim 20 \mu \mathrm{m})$. This intrusion of Ti-powder into the Ti-felt substrate explains why the MPD of B1 and B2 changed only slightly with Ti-powder loading, whereas $\varepsilon$ decreased (Table 1). In particular, the MPD and BPD of B1-2 were larger than B1-1. It must be caused by the quality unevenness of Ti-felt substrate, namely, the original substrate of Ti-felt of B1-2 had relatively large pores though $\phi$ and $\varepsilon$ were the same as the A1. The pore size distribution of Ti-felt was measured with the mercury intrusion porosimetry (MIP). Based on MIP data of A1 and B1s, we could observe only slight decrease of the main peak around $40-60 \mu \mathrm{m}$ by the loading of Ti-powder, though a increase of meso-pore $(0.05-7 \mu \mathrm{m})$ volume was detected [24]. In the case of B3, the loaded Ti-powder formed a layer on the Ti-felt substrate, because both $d_{\mathrm{p}}$ and $\varepsilon$ of the bare Ti-felt substrate (A3) were small. The MPD of B3 decreased significantly compared to that of A3. Therefore, the pore size distribution in through-plane direction of B3 (Ti-powder loaded Ti-felt) might differ from that of the B1 series and B2. Nevertheless, comparison of Figs. $2 \mathrm{~A}$ and $2 \mathrm{~B}$ reveals that the $i-V$ 
characteristics were influenced more strongly by $d_{\mathrm{p}}$ (i.e., MPD and BPD) of the anode current collector than by the pore structural difference caused by the Ti-powder loading.

In our previous study [8], Ti-felt without Ti-powder loading was treated with PTFE emulsion (10 and 20 wt.\%) and had a loaded PTFE amount of about 75 and 150 $\mathrm{mg} / \mathrm{cm}^{3}$ based on the outer geometric dimension of the Ti-felt substrate. These PTFE-coated Ti-felt substrates were used as the anode current collector in cells during electrolysis experiments. No noticeable difference was detected in the performance of these cells with that of cells with untreated Ti-felt substrates. In our current study, the PTFE loading in Ti-powder loaded substrates ranged between 1.0 and $3.0 \mathrm{mg} / \mathrm{cm}^{3}$, which is far lower than that in our previous study [8]. However, because all of the cells in our current study used MEA designed for an URFC, they can also be used as fuel cells. The cell ohmic resistance was observed in situ during FC operation using the AC impedance method at the same cell temperature $\left(80^{\circ} \mathrm{C}\right)$. As we reported $[24,25]$, the cell resistance depended on the humidification condition of the supplied gases during FC operation, and under the same humidification condition, loading of Ti-powder and PTFE onto the Ti-felt substrate had no effect on cell resistance.

Based on these results, changes in $d_{\mathrm{p}}$ of the porous current collectors affect the cell performance, as reflected by both the BPD and MPD of A2 and B2 being 
significantly larger than those of the other substrates (Table 1). Figure 3 A and 3B show the plot of $V$ (at $\left.i=1.017 / \mathrm{cm}^{2}\right)$ versus BPD and MPD, respectively. It was suggested that there is a close relationship between cell performance and $d_{\mathrm{p}}$ of the anode current collectors, though the data are rather scattered. As described above, the meso-pore volume $\left(0.05^{-7} \mu \mathrm{m}\right)$ was increased by the loading of Ti-powder [24]. However, we could not observe certain effect of meso-pores on the electrolysis performance. In addition, the cell performance improved with decreasing $d_{\mathrm{p}}$ when the MPD $>10 \mu \mathrm{m}$, which agrees with the tendency reported by Grigoriev et al. [7].

\subsection{Flow pattern of two-phase flow in the channels}

Based on our experimental results, this section discusses the relationship between cell performance and the flow pattern of the two-phase flow in the flow channel of the anode bipolar plate.

Despite considerable differences in the reported definition of two-phase flow patterns in channels [26-37], it is generally agreed that flow regimes consist of dispersed bubbly flow, slug flow, churn flow, and annular flow. Such typical flow regimes in these channels are schematically shown in Fig. 4, including plug flow as a transition flow (Fig. 4b). In the dispersed bubbly flow (Fig. 4A), liquid flowing in the channels is in 
the continuous phase while gas is dispersed in the continuous liquid phase as discrete small bubbles, when the bubble size $\left(d_{\mathrm{b}}\right)$ is smaller than the channel diameter $\left(d_{\text {chan }}\right)$. Plug flow (Fig. 4B) is the transition from bubbly flow to slug flow and consists of elongated bubbles whose $d_{\mathrm{b}}>d_{\text {chan }}$. This flow pattern has also been referred to as slug flow [26], elongated bubble flow [27], wedging flow [28], and confined bubble flow [29]. As the mass flow rate of gas is increased (which leads to increasing void fraction), bubbles develop into a bullet shape as slug flow (Fig. 4C), where $d_{\mathrm{b}}>d_{\text {chan }}$. Churn flow (Fig. 4D) is formed by the breakdown of these large bubbles in the slug flow, and the gas flows in a more chaotic manner through the liquid with oscillatory or time variant characteristics. In annular flow (Fig. 4E), gas phase becomes continuous flow in the core of the channel, and the liquid flows only along the walls of the channel as a film.

In general, the flow pattern of two-phase flow can be categorized by the superficial velocities of the gas and liquid $\left(j_{\mathrm{G}}\right.$ and $j_{\mathrm{L}}$, respectively), which can be calculated as follows:

$$
\left.\begin{array}{c}
j_{\mathrm{G}}=\left(G_{\mathrm{G}}+G_{\mathrm{L}}\right) x / \rho_{\mathrm{G}} \\
j_{\mathrm{L}}=\left(G_{\mathrm{G}}+G_{\mathrm{L}}\right)(1-x) / \rho_{\mathrm{L}}
\end{array}\right\}
$$

where $G_{\mathrm{G}}$ and $G_{\mathrm{L}}$ are the mass fluxes of the gas and liquid, $\rho_{\mathrm{G}}$ and $\rho_{\mathrm{L}}$ are the densities of gas and liquid, respectively, and $x$ is the quality of the two-phase flow 
defined as follows at an arbitrary location along the channel:

$$
x=\frac{G_{\mathrm{G}}}{G_{\mathrm{L}}+G_{\mathrm{G}}}
$$

In our previous study [9], the flow pattern was compared and analyzed using the flow map presented by Mishima and Hibiki [30]. To investigate the relation between flow pattern of two-phase flow and pore diameter of current collector, in the present study, the flow pattern was analyzed in more detail by doing an extended survey of literature [26-37] in terms of mini-channels, whose channel diameter ranged from 0.5 to $2.0 \mathrm{~mm}$. For mini-channels, under the same given $j_{\mathrm{G}}$ and $j_{\mathrm{L}}$, the flow pattern for vertical flow is quite similar to that for horizontal flow [32,33]. This similarity indicates that compared to the effect of buoyancy, the effect of surface tension is predominant in mini-channels of this size $[26,29]$.

Figures 5A and 5B compare the flow regime map presented by Mishima and Hibiki [30] and that by Ide et al. [33] and by Cubaud and Ho [28], respectively. Mishima and Hibiki obtained the map based on experiments with vertical upward flow in circular channels whose diameters were 1.05 and $2.05 \mathrm{~mm}$ [30]. Ide et al. [32,33] obtained the map based on similar experiments as Mishima and Hibiki, except the channel diameters were 1.0, 2.4, and $4.9 \mathrm{~mm}$. Cubaud and Ho [28] observed flow in horizontal rectangular channels whose square cross-sectional height (and width) was 0.2 and 0.525 
mm. In the anode channel of a PEM electrolyzer, the quality at the channel exit $\left(x_{\text {exit }}\right)$ can be calculated per channel as follows [9]:

$$
x_{\text {exit }}=\frac{G_{\mathrm{O}_{2}}}{G_{\text {circ }}-G_{\text {cons }}-G_{\text {drag }}+G_{\mathrm{O}_{2}}}
$$

where $G_{\mathrm{O}_{2}}$ is the mass flux of produced oxygen gas by the anode reaction, $G_{\text {circ }}$ is the mass flux of circulating water through the channel, $G_{\text {cons }}$ is the mass flux of consumed by the anode reaction, and $G_{\text {drag }}$ is the mass flux of the water "dragged" by electro-osmosis. Table 2 summarizes the detailed definitions of $G_{\mathrm{O}_{2}}, G_{\text {circ }}, G_{\text {cons }}$, and $G_{\text {drag }}$. Here, $j_{\mathrm{G}}$ and $j_{\mathrm{L}}$ at the channel exit of electrolyzer were calculated using Eqs. 2 and 4, assuming that $x$ changes linearly along the channel from zero to $x_{\text {exit. }}$ Figure 5 also shows the calculated $j_{\mathrm{G}}$ and $j_{\mathrm{L}}$ in the anode channel of the electrolyzer during electrolysis at $i=0.2,0.5,1.0,2.0$, and $3.0 \mathrm{~A} / \mathrm{cm}^{2}$. Based on the flow map and the description by Ide et al. [32,33] and Cubaud and Ho [28], dispersed bubbly flow (Fig. 4A) can be observed only under a limited condition, namely, at high liquid flow rate and low gas flow rate (represented by the upper-left region in Fig. 5). In general, transition from plug flow to slug flow is not clear, because at these flow patterns the bubble length $\left(l_{\mathrm{b}}\right)$ gradually increases with increasing mass flow rate of the gas. Triplett et al. [26] did not define plug flow, and Ide et al [33] (Fig. 5A) and Coleman and Garimella [27] merged plug flow and slug flow into an intermittent flow. The wedging flow defined by Cubaud 
and Ho (Fig. 5b) is nearly equal to the plug flow noted here (Fig. 4B). Comparison of flow regime maps shown in Figs. 5A and 5B reveals that the bubbly flow defined by Mishima and Hibiki [30] contains plug flow, and therefore dispersed bubbly flow might exist only near the inlet in the anode channel of the electrolyzer. As shown in Fig. 5, the flow regime of oxygen and water in the anode channel in our current study was apparently plug flow over almost the entire flow field when $i<1.0 \mathrm{~A} \mathrm{~cm}^{-2}$, and became slug flow near the exit of the channel when $i>2.0 \mathrm{~A} \mathrm{~cm}^{-2}$.

As described in Sec. 1, the two-phase flow of gas and liquid observed at the anode channel of a PEM electrolyzer can be observed at the anode channel of a DMFC, and visualization of this two-phase flow (using $\mathrm{CO}_{2}$ as the gas and methanol solution as the liquid) has been reported in several studies [12-20]. In general, the mass transfer of liquid from a channel to an electrode is significantly hindered by the residence of long bubbles (slugs) in the channel. Argyropoulos et al. [12] and Lu and Wang [15] discussed the relationship between the properties of GDL (corresponds to the current collector of the electrolyzer) and the flow regime in a channel. They pointed out that the detachment diameter of bubbles $\left(d_{\text {b-det }}\right)$ released from the porous current collector is crucial for the flow regime. Theoretically, $d_{\mathrm{b}-\mathrm{det}}$ in an open water pool when gas is injected through an orifice can be predicted by an equation given by Wallis [38,39] as 


$$
d_{\text {b-det }}=2\left[\frac{\gamma d_{\text {p-ori }}}{2 g\left(\rho_{\mathrm{L}}-\rho_{\mathrm{G}}\right)}\right]^{1 / 3}
$$

where $d_{\mathrm{p}-\text { ori }}$ is the orifice diameter, and $g$ is gravity, Using the physical properties of water and oxygen at $80^{\circ} \mathrm{C}$ in Eq. (5), the calculated $d_{\mathrm{b} \text {-det }}$ is $0.61 \mathrm{~mm}$ for $d_{\mathrm{p} \text {-ori }}=10 \mu \mathrm{m}$, $0.88 \mathrm{~mm}$ for $d_{\mathrm{p}-\text { ori }}=30 \mu \mathrm{m}$, and $1.32 \mathrm{~mm}$ for $d_{\mathrm{p} \text {-ori }}=100 \mu \mathrm{m}$. These theoretical estimates are comparable with the observed data for DMFC with a carbon paper GDL $[12,15]$. In addition, considering the principle of CFP as described in Sec. 2.2, $d_{\mathrm{p}}$ measured by CFP corresponds to $d_{\mathrm{p}-\text { ori }}$ that releases the bubbles. The length of a bubble (slug) in the channel $\left(l_{\mathrm{b}}\right)$ must increase with increasing $d_{\mathrm{b} \text {-det }}$ injected in the channel flow. Considering the flow regime, the difference in $d_{\mathrm{b}-\text { det }}$ can affect the transition from plug to slug, that is, the large bubbles that detach from large pores tend to induce the transition from plug to slug at lower mass flow rate of the gas, as discussed by Song et al. [40] and Guet et al. [41]. This tendency corresponds to a shift in the boundary of plug and slug to the left in the flow regime map. Several studies of DMFC $[15,16,18]$ suggest that an increase in $l_{\mathrm{b}}$ leads to an increase in the bubble coverage on the surface of the current collector. A long slug might restrict the continuous supply of liquid water through the current collector to the electrode, eventually hindering the mass transfer of water. Consequently, the dependence of cell voltage on $d_{\mathrm{p}}$ (BPD and MPD) shown in Fig. 3 can be explained by the bubble diameter detached from the current collector (i.e., 
$\left.d_{\text {b-det }}\right)$ and the degree of bubble coverage on the surface of the current collector.

\subsection{Curve fitting and estimation of proton conductivity of the membrane}

The mass transfer of liquid water to the electrode surface might be restricted by bubbles in the channel. Thus, a lower water supply can be assumed to decrease the water content in the membrane and thus increase the cell resistance, because proton conductivity of a PEM depends on the water content. Because we could not prepare an instrument for the cell impedance measurement at that time, the cell resistance could not be observed directly during electrolysis. Therefore, we estimated it by fitting the $i-V$ curves as follows.

In this work, we applied a simple model for PEM electrolysis developed by Garcia-Valverde et al. [11] to fit the $i-V$ curves. The overall expression of the model is

$$
V=E_{\text {rev }}+\frac{R T}{\alpha_{\mathrm{A}} z F} \ln \left(\frac{i}{i_{0, \mathrm{~A}}}\right)+\frac{R T}{\alpha_{\mathrm{C}} z F} \ln \left(\frac{i}{i_{0, \mathrm{C}}}\right)+\left(R_{\text {ele }}+R_{\mathrm{ion}}\right) i
$$

where $E_{\text {rev }}$ is the reversible voltage for water electrolysis, $z$ is the stoichiometric coefficient for transferred electrons, $\alpha_{\mathrm{A}}, \alpha_{\mathrm{C}}$ and $i_{0, \mathrm{~A}}, i_{0, \mathrm{C}}$ are the charge transfer coefficient and the exchange current density of the anode and cathode, respectively, $R_{\text {ele }}$ and $R_{\text {ion }}$ are the electronic and ionic contribution to the resistance losses, and $R, T$, and $F$ have their usual meaning. In this model, we did not consider the limiting current density, because 
the effect of mass transport limitation was not observed in the $i-V$ characteristics in our present study. The $E_{\text {rev }}$ at atmospheric pressure was determined by using an expression by LeRoy et al. [42,43]:

$$
E_{\text {rev }}=1.5184-1.5421 \times 10^{-3} T+9.523 \times 10^{-5} T \ln T+9.84 \times 10^{-8} T^{2}
$$

In water electrolysis, $z=2$, and in our present study, $\alpha$ was assumed to be 0.5 , the same as in the study by Garcia-Valverde et al. [11]. The second and third term of right-hand side of Eq. (6) denote the activation overpotential of the anode and cathode, respectively. Because $i_{0, \mathrm{C}} \gg i_{0, \mathrm{~A}}$ at usual electrodes of a PEM electrolyzer using Pt catalyst for the cathode [10], the activation overpotential of the cathode (the second term) can be neglected. The fourth term is the ohmic overpotential consisting of the electronic and ionic resistances ( $R_{\text {ele }} i$ and $R_{\text {ion }} i$, respectively). As mentioned in Sec. 3.1, cell resistance could be observed during the FC mode of the URFC. In the present cell set-ups, $R_{\text {ion }}$ is apparently predominant compared to $R_{\text {ele }}$. Because $R_{\text {ion }}$ is actually governed by the proton conductivity of the PEM, it is denoted as $R_{\text {mem. }}$ Eq. (6) can thus be rewritten as [11]

$$
V=E_{\mathrm{rev}}+\frac{R T}{2 \times 0.5 \times F} \ln \left(\frac{i}{i_{0, \mathrm{~A}}}\right)+R_{\mathrm{mem}} i
$$

Under the constant temperature $\left(80^{\circ} \mathrm{C}\right)$ in our experiments, $i_{0, \mathrm{~A}}$ and $R_{\mathrm{mem}}$ were the variable parameters in our fitting calculation of the $i-V$ curves. 
Figure 6 shows representative comparison (A1) in the $i-V$ curve between the experimental data and fitted curve using Eq. (8). The fitted curve agrees well with the experimental data over the entire range of $i$. Table 3 summarizes the parameters of the fitted curves. In the fitting calculations, the standard deviations of $i_{0, \mathrm{~A}}$ and $R_{\mathrm{mem}}$ are about two-orders smaller than the respective fitted value. The fitted value of $R_{\mathrm{mem}}$ for $\mathrm{A} 2$ and B2 was significantly larger whereas $i_{0, \mathrm{~A}}$ was slightly smaller than those for the other cells. Figure 7 shows the relationship between $R_{\text {mem_cal }}$ and $\log d_{\mathrm{p}}$, revealing that in the measured range of $d_{\mathrm{p}}$, namely, $25-552 \mu \mathrm{m}$ for BPD and $10-107 \mu \mathrm{m}$ for MPD, $R_{\text {mem_cal }}$ depended on $d_{\mathrm{p}}$. This dependence indicates that the large bubbles detached from large pores tend to hinder the water supply to the electrode (i.e., to the membrane), and thus decrease the proton conductivity in the membrane.

Figure 8 compares the proton conductivity $(\kappa)$ between the fitted value that we obtained here and the measured data and correlation reported in other studies [44-48]. In this figure, the data from Biaku et al. [49] is fitted values using the $i-V$ curves of PEM electrolysis, the same as done here in our present study. The range of fitted values from our study is lower than the data from Zawodzinski et al [45] and Kopitzke et al [47] As we previously reviewed [50], $\kappa$ of a membrane decreases when the membrane is pretreated by drying at elevated temperature over $100{ }^{\circ} \mathrm{C}$. The data from Parthasarathy 
et al. [44] was obtained for a membrane with the drying pretreatment at elevated temperature, whereas that from Zawodzinski et al. [45] and Kopitzke et al. [47] was obtained for a membrane without such treatment. Because the MEA that we used was fabricated by hot-pressing and thus dried at an elevated temperature over $100{ }^{\circ} \mathrm{C}$, the $\kappa$ range in our study is reasonable.

In the present analysis on the overpotential, since the simple model (Eq. 8) was applied, the difference of the cell voltage was represented only by the difference of the $R_{\mathrm{mem}}$. However, there is a possibility that the $R_{\mathrm{mem}}$ depends on $i$ and the overpotential contains other constituents than the anode activation overpotential and the ohmic overpotential (i.e., the concentration overpotential and the cathode activation overpotential). As for these ambiguous points, it is planned to pursue a close investigation in future.

\section{Conclusions}

The effect of changes in pore structure of the anode current collector on PEM electrolysis performance was experimentally investigated using a small cell with various Ti-felt substrates of different fiber diameter and porosity and with Ti-felts loaded with Ti-powder as the anode current collectors. The pore diameter of these cells 
was measured by capillary flow porometry.

Experimental results show that, when the mean pore diameter of the porous current collector was larger than $10 \mu \mathrm{m}$, the electrolysis performance improved with decreasing pore diameter, regardless of the type of porous current collector studied here. In contrast, changes in porosity had no significant effect on the cell performance when the porosity exceeded about 0.50 . The results also revealed that (a) the pore diameter affects the flow regime, (b) mass transfer of liquid water to the electrode surface might be restricted by bubbles in the channel, and (c) larger bubbles generated from larger pores tend to become long slugs and thus hinder the water supply to the membrane. 


\section{Nomenclature}

electrode surface area, $\mathrm{m}^{2}$

B

capillary constant

$a$

cross-sectional area of flow channel, $\mathrm{m}^{2}$

$d_{\text {chan }}$

hydraulic diameter of the channel, mm

$d_{\mathrm{b}}$

bubble diameter, $\mu \mathrm{m}$

$d_{\text {b-det }}$

detachment bubble diameter, $\mu \mathrm{m}$

$d_{\mathrm{p}}$

pore diameter of the porous media, $\mu \mathrm{m}$

$d_{\mathrm{p}-\mathrm{ori}}$

pore diameter of orifice, $\mu \mathrm{m}$

F

Faraday constant, $\mathrm{C} \mathrm{mol}^{-1}$

G

mass flux in the channel, $\mathrm{kg} \mathrm{m}^{-2} \mathrm{~s}^{-1}$

i

current density, $\mathrm{A} \mathrm{cm}^{-2}$

$i_{0}$

exchange current density, $\mathrm{A} \mathrm{cm}^{-2}$

$l_{\mathrm{b}}$

length of a bubble in the channel, mm

M

molar weight, $\mathrm{kg} \mathrm{mol}^{-1}$

$n_{\text {chan }}$

number of channels in parallel in the flow field

$P$

pressure, $\mathrm{Pa}$

$Q$

flow rate of circulating water, $\mathrm{m}^{3} \mathrm{~s}^{-1}\left(\mathrm{~L} \mathrm{~min}^{-1}\right)$ 


$\begin{array}{ll}R & \text { gas constant, } \mathrm{J} \mathrm{mol}^{-1} \mathrm{~K}^{-1} \\ R_{\text {ele }} & \text { electronic resistance, } \Omega \mathrm{cm}^{2} \\ R_{\text {ion }} & \text { ionic resistance, } \Omega \mathrm{cm}^{2} \\ R_{\text {mem }} & \text { membrane resistance, } \Omega \mathrm{cm}^{2} \\ T & \text { temperature, } \mathrm{K}\left({ }^{\circ} \mathrm{C}\right) \\ V & \text { cell voltage at electrolysis, } \mathrm{V} \\ Z & \text { stoichiometric coefficient for transferred electron }\end{array}$

Greek symbols

$\alpha$

charge transfer coefficient

$\gamma$

surface tension, $\mathrm{N} \mathrm{m}^{-1}$

$\varepsilon$

porosity

$\theta$

contact angle, ${ }^{\circ}$

$\rho$

density, $\mathrm{kg} \mathrm{m}^{-3}$

$\phi$

fiber diameter, $\mu \mathrm{m}$

Subscripts

A

anode 


\begin{tabular}{ll} 
C & cathode \\
circ & circulation \\
cons & consumption \\
drag & drag \\
$\mathrm{G}$ & gas \\
$\mathrm{H}_{2} \mathrm{O}$ & water \\
$\mathrm{L}$ & liquid \\
$\mathrm{O}_{2}$ & \\
\hline
\end{tabular}

Abbreviations

BOP balance of plant

BPD bubble point diameter

CFP capillary flow porometry

DMFC direct methanol fuel cell

GDL gas diffusion layer

MEA membrane electrode assembly

MPD mean pore diameter

PEM proton exchange membrane 
PEMFC

PTFE

URFC

proton exchange membrane fuel cell

polytetrafluoroethylene

unitized reversible fuel cell 


\section{References}

[1] Momirlan M, Veziroglu TN. Current status of hydrogen energy. Renewable Sustainable Energy Reviews 2002; 6: 141-179.

[2] Zoulias EI, Glockner R, Lymberopoulos N, Tsoutsos T, Vosseler I, Gavalda O, Mydske HJ, Taylor P. Integration of hydrogen energy technologies in stand-alone power systems analysis of the current potential for applications. Renewable Sustainable Energy Reviews 2006; 10: 432-462.

[3] Barbir F. PEM electrolysis for production of hydrogen from renewable energy sources. Solar Energy 2005; 78: 661-669.

[4] García-Valverde R, Miguel C, Martínez-Béjar R, Urbina A. Optimized photovoltaic generator-water electrolyser coupling through a controlled DC-DC converter. Int J Hydrog Energy 2008; 33: 5352-5362.

[5] Millet P, Dragoe D, Grigoriev S, Fateev V, Etievant C. GenHyPEM: A research program on PEM water electrolysis supported by the European Commission. Int $\mathrm{J}$ Hydrog Energy 2009; 34: 4974-4982.

[6] Ayers KE, Anderson EB, Capuano CB, Carter BD, Dalton LT, Hanlon G, Manco J, Niedzwiecki M. Research advances towards low cost, high efficiency PEM electrolysis. ECS Transactions 2010; 33(1): 3-15.

[7] Grigoriev SA, Millet P, Volobuev SA, Fateev VN. Optimization of porous current collectors for PEM water electrolysers. Int J Hydrog Energy 2009; 34: 4968-4973.

[8] Hwang CM, Ishida M, Ito H, Maeda T, Nakano A, Hasegawa Y, Yokoi N, Kato A, Yoshida T. Influence of properties of gas diffusion layers on the performance of polymer electrolyte-based unitized reversible fuel cells. Int J Hydrog Energy 2011; 
36: $1740-1753$.

[9] Ito H, Maeda T, Nakano A, Hasegawa Y, Yokoi N, Hwang CM, Ishida M, Kato A, Yoshida T. Effect of flow regime of circulating water on a proton exchange membrane electrolyzer. Int J Hydrog Energy 2010; 35: 9550-9560.

[10] Choi P, Bassarabov DG, Datta R. A simple model for solid polymer electrolyte (SPE) water electrolysis. Solid State Ionics 2004; 175: 535-539.

[11] García-Valverde R, Espinosa N, Urbina A. Optimized method for photovoltaic-water electrolyser direct coupling. Int J Hydrog Energy 2011; 36: 10574-10586.

[12] Argyropoulos P, Scott K, Taama WM. Gas evolution and power performance in direct methanol fuel cells. J Appl Electrochem 1999; 29: 661-669.

[13] Argyropoulos P, Scott K, Taama WM. Carbon dioxide evolution patterns in direct methanol fuel cells. Electrochim Acta 1999; 44: 3575-3584.

[14] Scott K, Argyropoulos P, Yiannopoulos P, Taama WM. Electrochemical and gas evolution characteristics of direct methanol fuel cells with stainless steel mesh flow beds. J Appl Electrochem 2001; 31: 823-832.

[15] Lu CQ, Wang CY. Electrochemical and flow characterization of a direct methanol fuel cell. J Power Sources 2004; 134: 33-40.

[16] Yang $\mathrm{H}$, Zhao TS, Ye Q. In situ visualization study of $\mathrm{CO}_{2}$ gas bubble behavior in DMFC anode flow fields. J Power Sources 2005; 139: 79-90.

[17] Yang H, Zhao TS. Effect of anode flow field design on the performance of liquid feed direct methanol fuel cells. Electrochim Acta 2005; 50: 3243-3252.

[18] Wong CW, Zhao TS, Ye Q, Liu JG. Transient capillary blocking in the flow field of a micro-DMFC and its effect on cell performance. J Electrochem Soc 2005; 152: A1600-A1605. 
[19] Zhang J, Yin GP, Lai QZ, Wang ZB, Cai KD, Lin P. The influence of anode gas diffusion layer on the performance of low-temperature DMFC. J Power Sources $2007 ; 168: 453-458$

[20] Liao Q, Zhu X, Zheng X, Ding Y. Visualization study on the dynamics of $\mathrm{CO}_{2}$ bubbles in anode channels and performance of a DMFC. J Power Sources 2007; 171: 644-651.

[21] American Society for Testing, Material Committee, Standard Test Methods, for Pore Size Characteristics of Membrane Filters by Bubble Point and Mean Flow Pore Test, ASTM, F316-89, 1970, pp. 722-727..

[22] Jena A, Gupta K. An innovative technique for pore structure analysis of fuel cell and battery components using flow porometry. J Power Sources 2001; 96: 214-219.

[23] T. Kitahara, T. Konomi, H. Nakajima. Microporous layer coated gas diffusion layers for enhanced performance of polymer electrolyte fuel cells. J. Power Sources 2010; 195: 2202-2211.

[24] Hwang CM, Ishida M, Ito H, Maeda T, Nakano A, Kato A, Yoshida T. Effect of titanium powder loading on oxygen electrode gas diffusion layer of a polymer electrolyte unitized reversible fuel cell. J. Power Sources 2012; 202: 108-113.

[25] Ito H, Maeda T, Nakano A, Hwang CM, Ishida M, Kato A, Yoshida T. Effect of titanium powder loading in microporous layer on a polymer electrolyte unitized reversible fuel cell. ECS Trans 2011; 41 (1): 469-477.

[26] Triplett KA, Ghiaasiaan SM, Abdel-Khalik SI, Sadowski DL. Gas-liquid two-phase flow in microchannel, pert I Two-phase flow pattern. Int J Multiphase Flow 1999; 25: $377-394$.

[27] Coleman JW, Garimella S. Characterization of two-phase flow patterns in small 
diameter round and rectangular tubes. Int J heat Mass Transfer 1999; 42: 2869-2881.

[28] Cubaud T, Ho CM. Transport of bubbles in square microchannels. Phys Fluids $2004 ; 16: 4575-4585$.

[29] Chen L, Tian YS, Karayiannis TG. The effect of tube diameter on vertical two-phase flow regimes in small tubes. Int J Heat Mass Trans 2006; 49: 4220-4230.

[30] Mishima K, Hibiki T. Some characteristics of air-water two-phase flow in small diameter vertical tubes. Int J Multiphase Flow 1996; 22: 703-712.

[31] Kariyasaki A, Fukano T, Ousaka A, Kagawa M. Isothermal air-water two-phase up-and downward flows in a vertical capillary tube. Trans JSME B 1992; 58: 2684-2690. [in Japanese]

[32] Ide H, Matsumura H, Tanaka Y, Fukano T. Flow patterns and frictional pressure drop in gas-liquid two-phase flow in vertical capillary channels with rectangular cross section. Trans JSME B 1997; 63: 452-460. [in Japanese]

[33] Ide H, Kariyasaki A, Fukano T. Fundamental data on the gas-liquid two-phase flow in microchannels. Int J Thermal Science 2007; 46: 519-530.

[34] Xu JL, Cheng P, Zhao TS. Gas-liquid two-phase flow regimes in rectangular channels with mini/micro gaps. Int J Multiphase Flow 1999; 25: 411-432.

[35] Zhao TS, Bi QC. Co-current air-water two-phase flow patterns in vertical triangular microchannels. In J Multiphase Flow 2001; 27: 765-782.

[36] Kawahara A. Chung PMY, Kawaji M. Investigation of two-phase flow pattern, void fraction and pressure drop on a microchannel. Int J Multiphase Flow 2002; 22: 1411-1435.

[37] Akbar MK, Plummer DA, Ghiaasiaan SM. On gas-liquid two-phase flow regimes in 
microchannels. Int J Multiphase Flow 2003; 29: 855-865.

[38] Wallis GB, One-dimensional Two Phase Flow. McGraw-Hill, New York (1969).

[39] Bi QC, Zhao TS. Taylor bubbles in miniaturized circular and noncircular channels. Int J Multiphase Flow 2001; 27: 561-570.

[40] Song CH, No HC, Chung MK. Investigation of bubble flow developments and its transition based on the instability of void fraction waves. Int $\mathrm{J}$ Multiphase Flow 1995; 21: 381-404.

[41] Guet S, Ooms G, Oliemans RVA. Influence of bubble size on the transition from low-Re bubbly flow to slug flow in a vertical pipe. Experimental Thermal Fluid Sci 2002; $26: 635-641$.

[42] LeRoy RL, Bowen CT, LeRoy DJ, The thermodynamics of aqueous water electrolysis. J Electrochem Soc 1980; 127: 1954-1962.

[43] Onda K, Kyakuno T, Hattori K, Ito K. Prediction of production power for high-pressure hydrogen by high-pressure water electrolysis. J Power Sources 2004; 132: 64-70.

[44] Parthasarathy A, , Srinivasan S, Appleby AJ, Martin CR. Temperature dependence of the electrode kinetics of oxygen reduction at the platinum/Nafion interface $-\mathrm{A}$ microelectrode investigation. J Electrochem Soc 1992; 139: 2530-2537.

[45] Zawodzinski TZ, Derouin C, Radzinski S, Sherman RJ, Smith VT, Springer TE, Gottesfeld S. Water uptake by and transport through Nafion 117 membranes. J Electrochem Soc 1993; 140: 1041-1047.

[46] Springer TE, Zawodzinski TA, Gottesfeld S. Polymer electrolyte fuel cell model. J Electrochem Soc 1991; 138: 2334-2342.

[47] Kopitzke R, Linkous CA, Anderson HR, Nelson GL. Conductivity and water uptake 
of aromatic-based proton exchange membrane electrolytes. J Electrochem Soc 2000; 147: $1677-1681$.

[48] Doyle M, Lewittes ME, Roelofs MG, Perusich SA, Lowrey RE. Relationship between ionic conductivity of perfluorinated ionomeric membranes and nonaqueous solvent properties. J Mem Sci 2001; 184: 257-273.

[49] Biaku CY, Dale NV, Mann MD, Salehfar H, Peters AJ, Han T. A semiempirical study of the temperature dependence of the anode charge transfer coefficient of a 6 kW PEM electrolyzer. Int J Hydrog Energy 2008; 33: 4247-4254.

[50] Ito H, Maeda T, Nakano A, Takenaka H. Properties of Nafion membranes under PEM water electrolysis conditions. Int J Hydrog Energy2011; 36: 10527-10540. 


\section{Figure captions}

Figure 1. Schematic of (A) capillary flow porometry (CFP) measurement and (B) gas flow rate characteristics and definition of bubble point diameter (BPD) and mean pore diameter (MPD) for CFP measurement with curves of "wet flow", "dry flow", and "half-dry flow".

Figure 2. Current density (i) and voltage (V) of a PEM electrolyzer with different anode current collectors of (A) bare Ti-felt (A1, A2, A3) and (B) Ti-powder loaded Ti-felt (B1-2, B2, B3). Cell temperature $\left(T_{\text {cell }}\right)$ was $80^{\circ} \mathrm{C}$.

Figure 3. Cell voltage at $1.017 \mathrm{~A} / \mathrm{cm}^{2}$ versus (A) bubble point diameter (BPD) and (B) mean pore diameter (MPD) for Ti-felt substrates with and without Ti-powder loading as the oxygen-side current collector.

Figure 4. Schematic flow patterns of gas-liquid two-phase flow in channels.

Figure 5. Flow regime maps expressed by superficial velocity of gas $\left(j_{\mathrm{G}}\right)$ and liquid $\left(j_{\mathrm{L}}\right)$, (A) by Mishima and Hibiki [30] and Ide et al. [32,33], and (B) by Mishima and Hibiki and Cubaud and Ho [28]. Symbols indicate our calculated velocity in the channel of PEM electrolyzer from inlet to exit at each current density $i$ at $80^{\circ} \mathrm{C}$ and a flow rate of circulating water of $25 \mathrm{~mL} / \mathrm{min}$.

Figure 6. Representative comparison of current (i) - voltage (V) characteristics between experimental data (symbols) and fitted curve (line) using A1 as an example. 
Figure 7. Calculated membrane resistance $\left(R_{\text {mem_cal }}\right)$ versus logarithm of the pore diameter $\left(d_{\mathrm{p}}\right)$ for bubble point diameter (BPD) and mean pore diameter (MPD).

Figure 8. Arrhenius plots of proton conductivity $(\kappa)$ of a Nafion membrane immersed in liquid water reported in literature [44-49], correlations presented by Springer et al. [46] and Kopitzke et al. [47], fitted values with electrolysis data [49], and fitted value obtained in the present study.

Table 1. Properties of anode current collectors in the PEM electrolysis test.

Table 2. Parameters used in Eq. (4) to calculate the quality at the exit $\left(x_{\text {exit }}\right)$ of the anode channel of a PEM electrolyzer.

Table 3. Parameters calculated using Eq. (8) and standard deviation of fit to experimental data. 


\section{Figure 1}

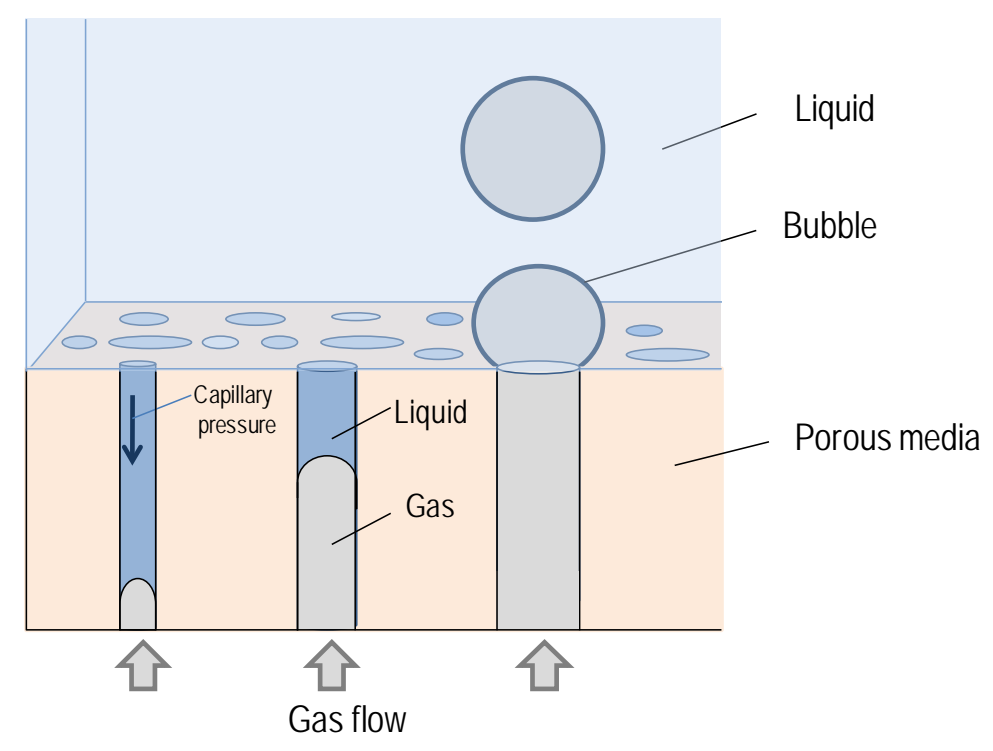

(A)

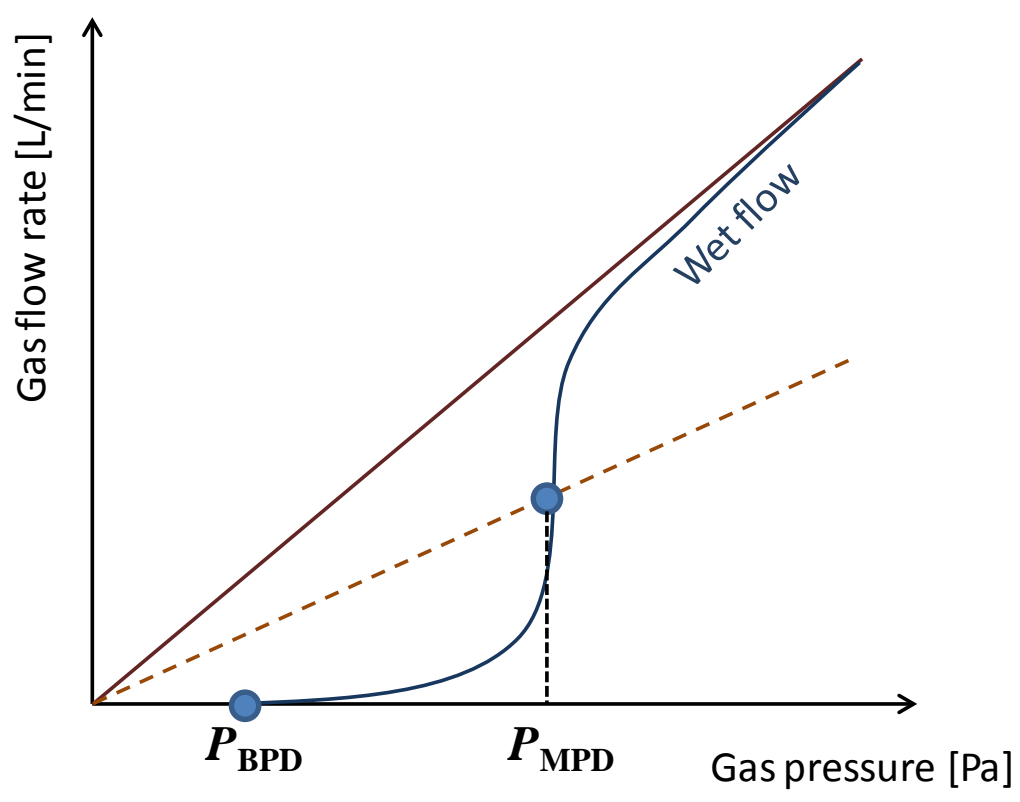

(B)

Figure 1. Schematic of (A) capillary flow porometry (CFP) measurement and (B) gas flow rate characteristics and definition of mean pore diameter for CFP measurement with curves of "wet flow", "dry flow", and "half-dry flow". 


\section{Figure 2}
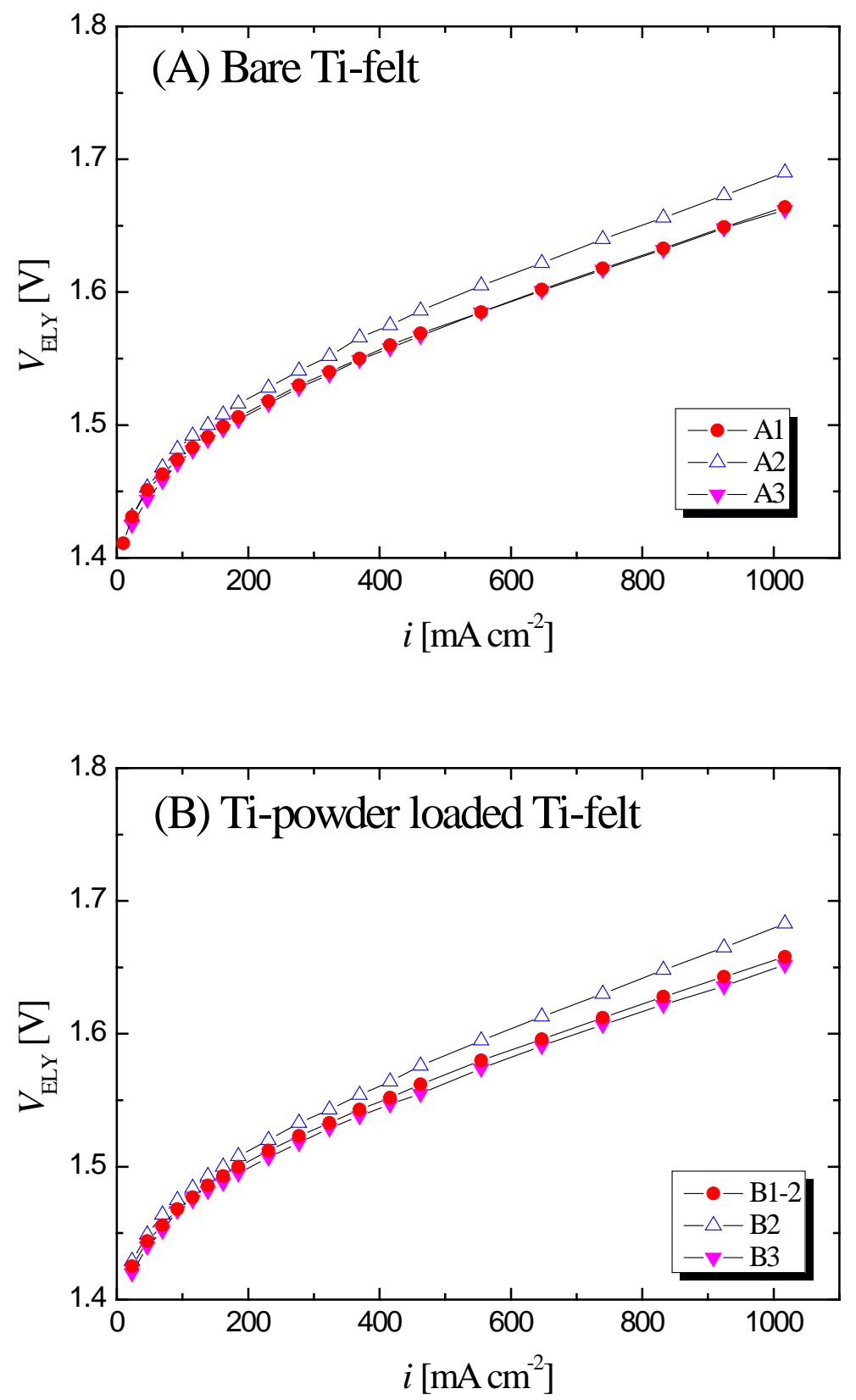

Figure 2. Current density (i) and voltage ( $V$ ) of a PEM electrolyzer with different anode current collectors of (A) bare Ti-felt (A1, A2, A3) and (B) Ti-powder loaded Ti-felt (B1-2, B2, B3). Cell temperature $\left(T_{\text {cell }}\right)$ was $80^{\circ} \mathrm{C}$. 


\section{Figure 3}
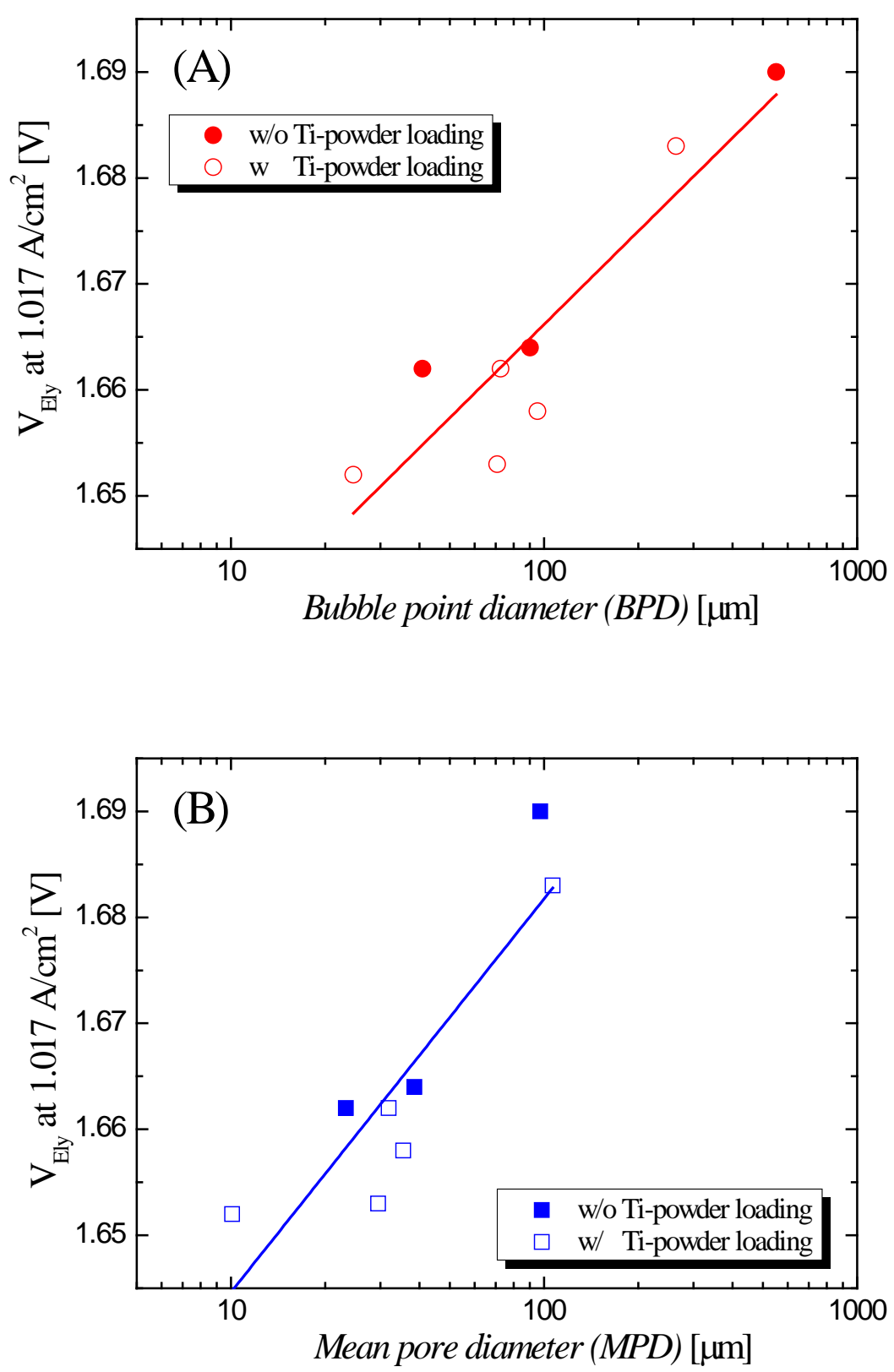

Figure 3. Cell voltage at $1.017 \mathrm{~A} / \mathrm{cm}^{2}$ versus (A) bubble point diameter (BPD) and (B) mean pore diameter (MPD) for Ti-felt substrates with and without Ti-powder loading as the oxygen-side current collector. 
Figure 4

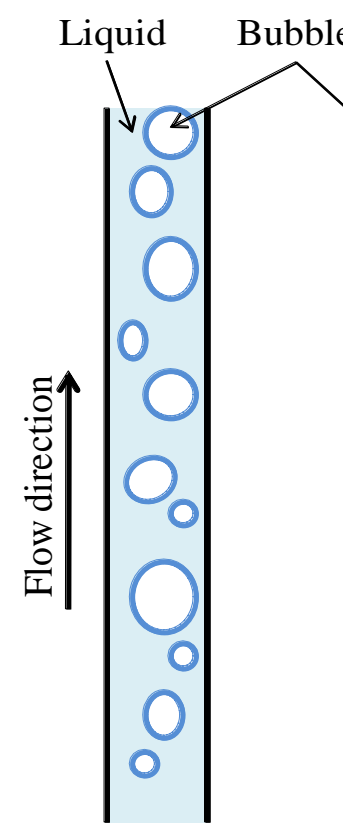

(A)

Dispersed bubbly

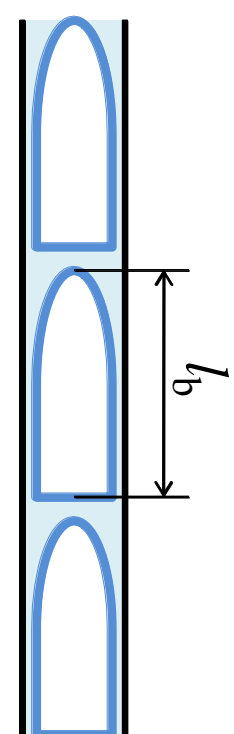

(C)

Slug

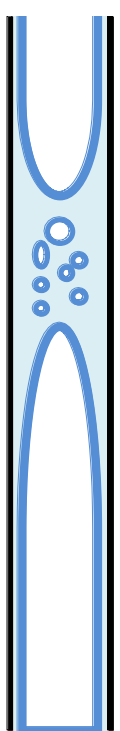

(D)

Churn

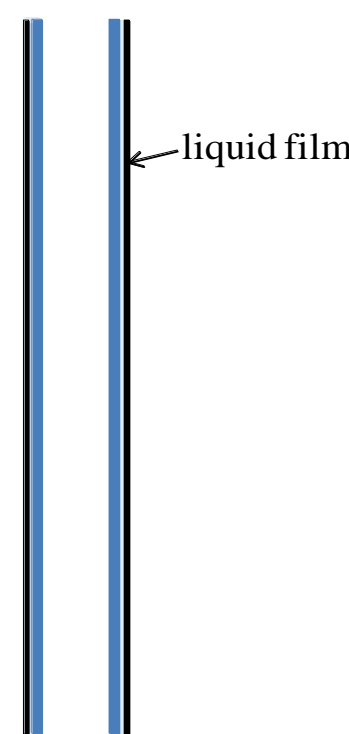

(E)

Figure 4. Schematic flow patterns of gas-liquid two-phase flow in channels. 


\section{Figure 5}
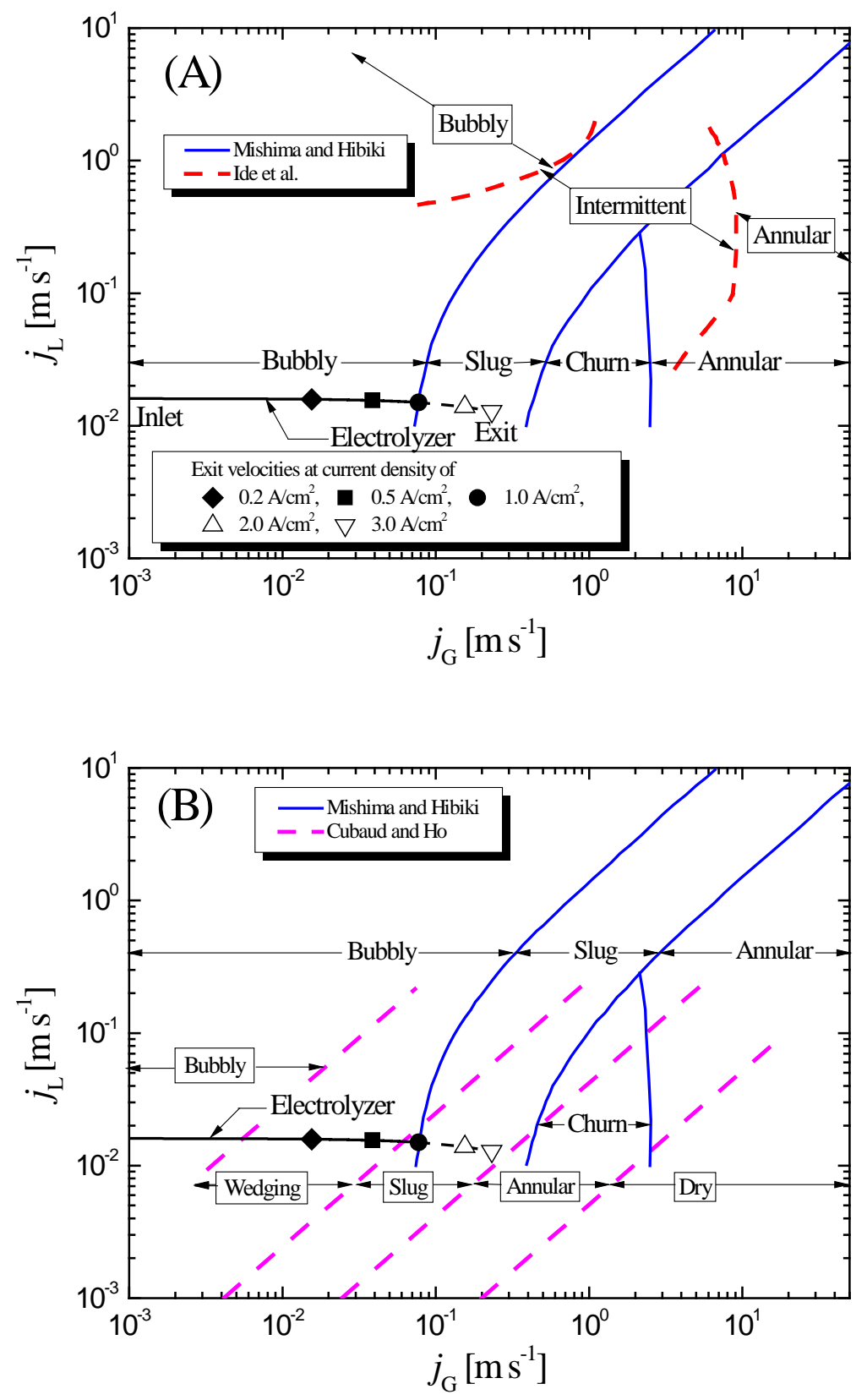

Figure 5. Flow regime maps expressed by superficial velocity of gas $\left(j_{\mathrm{G}}\right)$ and liquid $\left(j_{\mathrm{L}}\right)$, (A) by Mishima and Hibiki [30] and Ide et al. [32,33], and (B) by Mishima and Hibiki and Cubaud and Ho [28]. Symbols indicate our calculated velocity in the channel of PEM electrolyzer from inlet to exit at each current density $i$ at $80{ }^{\circ} \mathrm{C}$ and a flow rate of circulating water of $25 \mathrm{~mL} / \mathrm{min}$. 


\section{Figure 6}

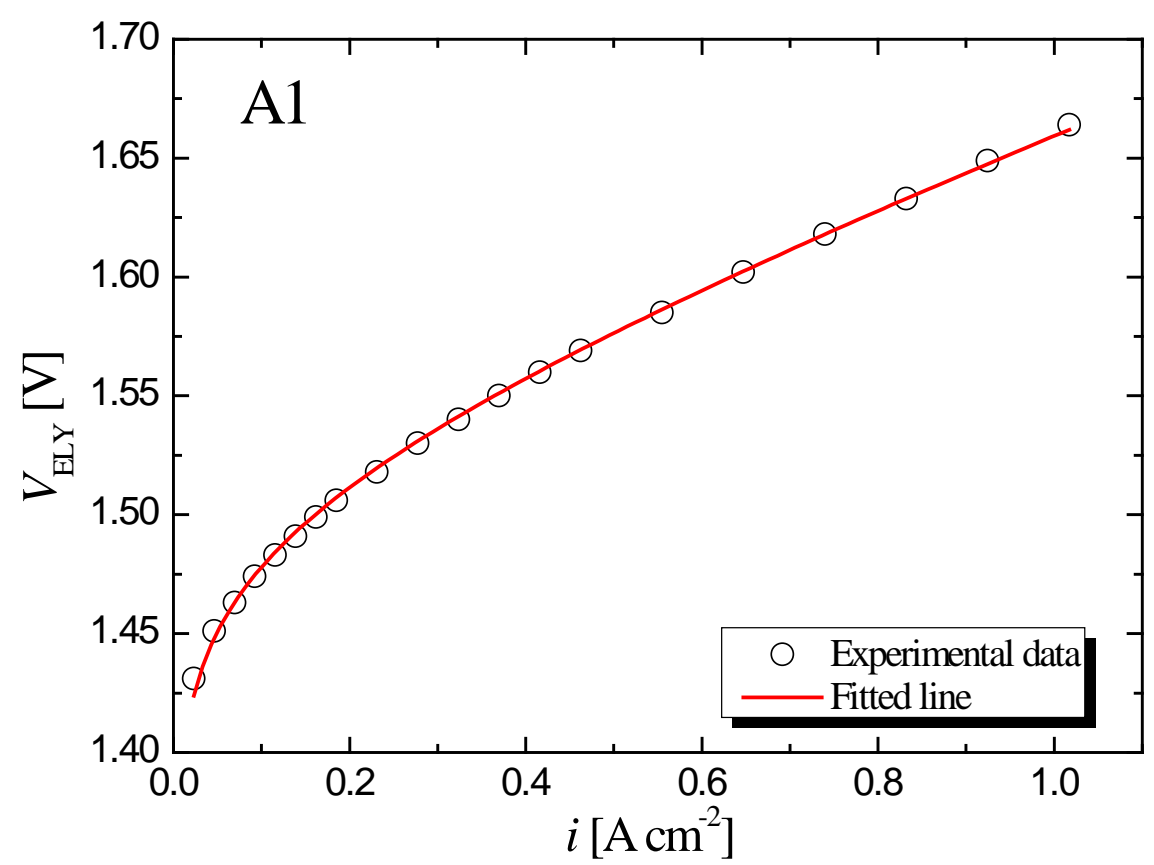

Figure 6. Representative comparison of current (i) - voltage ( $V)$ characteristics between experimental data (symbols) and fitted curve (line) using A1 as an example. 


\section{Figure 7}

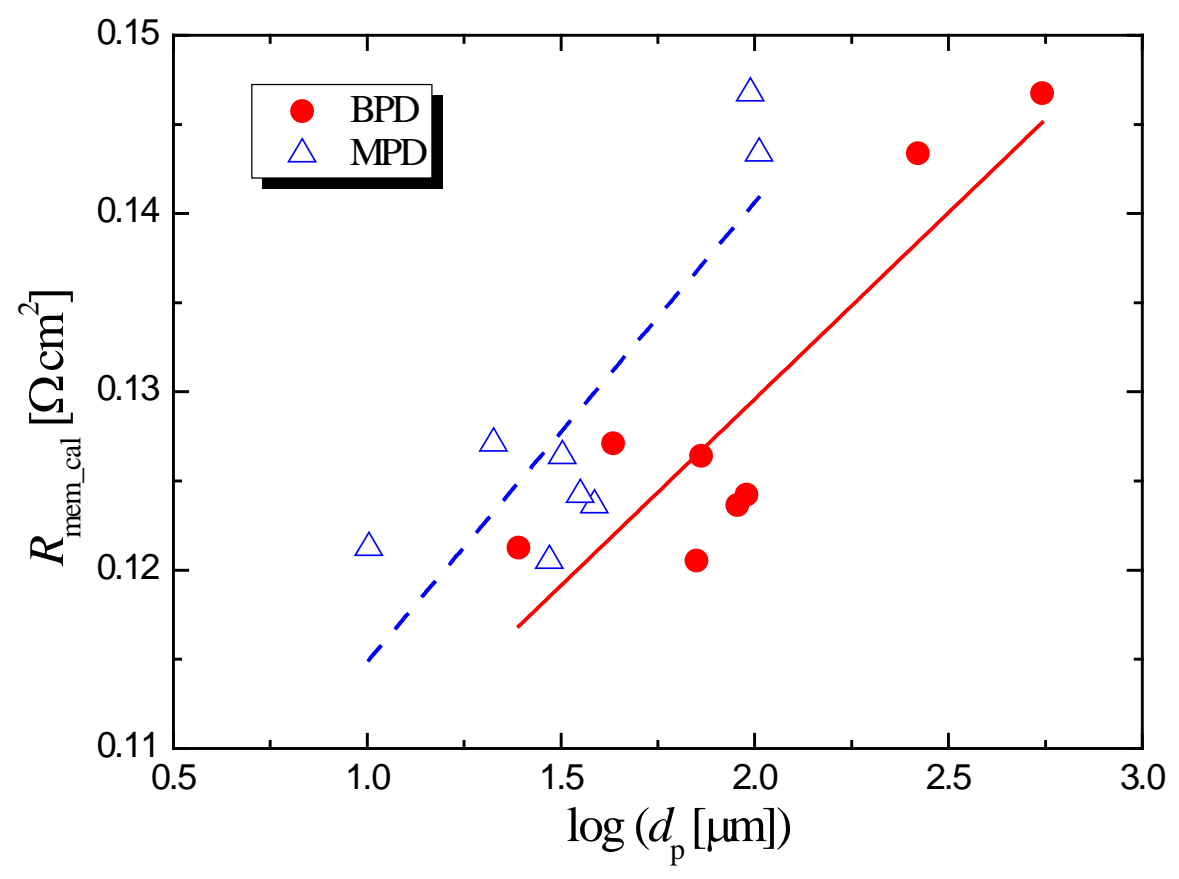

Figure 7. Calculated membrane resistance $\left(R_{\text {mem_cal }}\right)$ versus logarithm of the pore diameter $\left(d_{\mathrm{p}}\right)$ for bubble point diameter (BPD) and mean pore diameter (MPD). 


\section{Figure 8}

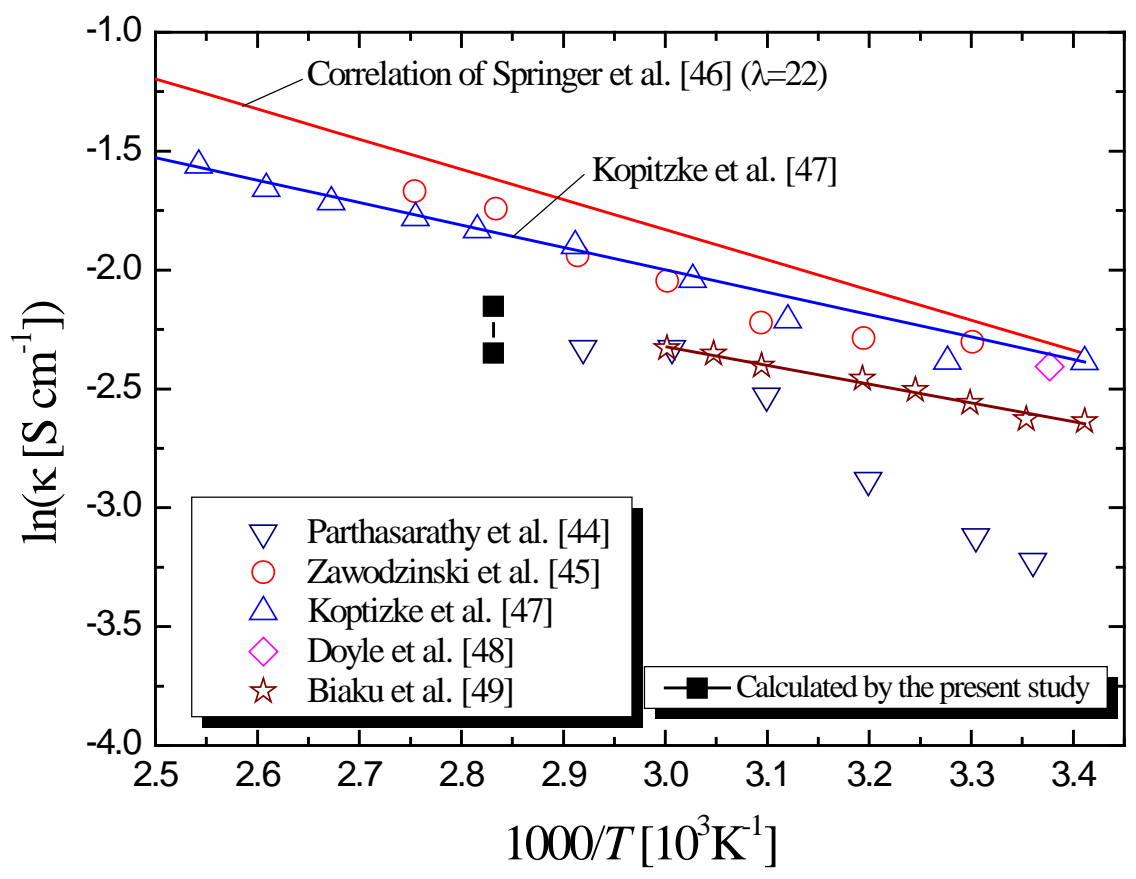

Figure 8. Arrhenius plots of proton conductivity $(\kappa)$ of a Nafion membrane immersed in liquid water reported in literature [44-49], correlations presented by Springer et al. [46] and Kopitzke et al. [47], fitted values with electrolysis data [49], and fitted value obtained in the present study. 


\section{Table 1}

Table 1. Properties of anode current collectors in the PEM electrolysis test. a

\begin{tabular}{|c|c|c|c|c|c|c|}
\hline $\begin{array}{c}\text { Cell } \\
\text { set-up } \\
\text { notation }\end{array}$ & $\begin{array}{l}\text { Current collector substrate } \\
\text { at oxygen-side }\end{array}$ & $\begin{array}{l}\text { Fiber diameter } \\
\text { of Ti-felt } \\
(\phi)\end{array}$ & $\begin{array}{l}\text { Porosity of } \\
\text { Ti-felt } \\
(\varepsilon)\end{array}$ & $\begin{array}{l}\text { Ti powder } \\
\text { loading }\end{array}$ & $\begin{array}{c}\text { Bubble } \\
\text { point } \\
\text { diameter } \\
{ }^{(B P D)^{c}}\end{array}$ & $\begin{array}{l}\text { Mean pore } \\
\text { diameter } \\
(\mathrm{MPD})^{\mathrm{c}}\end{array}$ \\
\hline & & {$[\mu \mathrm{m}]$} & - & {$\left[\mathrm{g} / \mathrm{cm}^{3}\right]$} & {$[\mu \mathrm{m}]$} & {$[\mu \mathrm{m}]$} \\
\hline A1 & Ti-felt & \multirow{4}{*}{20} & 0.75 & - & 90.2 & 38.6 \\
\hline B1-1 & Ti-felt + Ti powder & & $0.73^{d}$ & 0.11 & 72.7 & 31.9 \\
\hline B1-2 & Ti-felt + Ti powder & & $0.71^{\mathrm{d}}$ & 0.20 & 95.4 & 35.5 \\
\hline B1-3 & Ti-felt + Ti powder & & $0.68^{\mathrm{d}}$ & 0.30 & 70.8 & 29.5 \\
\hline A2 & Ti-felt & \multirow{2}{*}{80} & 0.75 & - & 551.5 & 97.4 \\
\hline B2 & Ti-felt + Ti powder & & $0.73^{d}$ & 0.20 & 264.0 & 106.5 \\
\hline A3 & Ti-felt & \multirow{2}{*}{20} & 0.50 & - & 43.1 & 21.2 \\
\hline B3 & Ti-felt + Ti powder & & $0.46^{\mathrm{d}}$ & 0.20 & 24.6 & 10.1 \\
\hline
\end{tabular}

a: Cathode current collector was the commonly used carbon paper.

b: Calculated based on amount of loaded Ti-powder and outer geometric dimension of Ti-felt substrate.

c: Measured by capillary flow porometry using the bubble point technique.

d: Calculated based on amount of loaded Ti-powder. 
Table 2

Table 2. Parameters used in Eq. (4).

\begin{tabular}{|l|c|c|c|}
\hline & Parameter & Equation & \\
\hline$G_{\mathrm{O}_{2}}$ & $\begin{array}{c}\text { mass flux of produced } \\
\text { oxygen gas }\end{array}$ & $\frac{i A M_{\mathrm{O}_{2}}}{4 F n_{\text {chan }} a}$ & \\
\hline$G_{\text {circ }}$ & $\begin{array}{c}\text { mass flux of circulating } \\
\text { water }\end{array}$ & $\frac{\rho_{\mathrm{H}_{2} \mathrm{O}} Q}{n_{\text {chan }} a}$ & \\
\hline$G_{\text {cons }}$ & $\begin{array}{c}\text { mass flux consumed by the } \\
\text { anode reaction } \\
\text { mass flux of the water } \\
\text { dragged by electro-osmosis }\end{array}$ & $\frac{i A M_{\mathrm{H}_{2} \mathrm{O}}}{2 F n_{\text {chan }} a}$ & \\
\hline$G_{\text {drag }}$ & $n_{\text {drag }} \frac{i A M_{\mathrm{H}_{2} \mathrm{O}}}{F n_{\text {chan }} a}$ & \\
\hline$n_{\text {drag }}$ & drag coefficient & $n_{\text {drag }}=0.0134 \times T+0.03$ & Ref. 42 \\
\hline
\end{tabular}


Table 3.

Table 3. Parameters calculated using Eq. (8) and standard deviation of fit to experimental data.

\begin{tabular}{ccccc}
\hline $\begin{array}{c}\text { Cell } \\
\text { set-up } \\
\text { notation }\end{array}$ & $\begin{array}{c}\text { Exchange } \\
\text { current density } \\
\text { of anode }\left(i_{0, \mathrm{~A}}\right)\end{array}$ & $\begin{array}{c}\text { Membrane resistance } \\
\left(R_{\mathrm{mem}}\right)\end{array}$ & $\begin{array}{c}\text { Standard } \\
\text { deviation of } i_{0, \mathrm{~A}}\end{array}$ & $\begin{array}{c}\text { Standard deviation } \\
\text { of } R_{\mathrm{mem}}\end{array}$ \\
\hline \hline A1 & $9.382 \mathrm{E}-06$ & 0.12365 & $2.407 \mathrm{E}-07$ & 0.00160 \\
{$\left[\mathrm{~cm}^{2}\right]$} & 0.12640 & $4.491 \mathrm{E}-07$ & 0.00246 \\
B1-1 & $1.143 \mathrm{E}-05$ & 0.12423 & $3.119 \mathrm{E}-07$ & 0.00168 \\
B1-2 & $1.161 \mathrm{E}-05$ & 0.12053 & $3.796 \mathrm{E}-07$ & 0.00192 \\
B1-3 & $1.235 \mathrm{E}-05$ & 0.14675 & $1.012 \mathrm{E}-07$ & 0.00078 \\
A2 & $8.069 \mathrm{E}-06$ & 0.14338 & $2.726 \mathrm{E}-07$ & 0.00170 \\
B2 & $1.003 \mathrm{E}-05$ & 0.12712 & $1.558 \mathrm{E}-07$ & 0.00092 \\
A3 & $1.057 \mathrm{E}-05$ & 0.12125 & $3.682 \mathrm{E}-07$ & 0.00176 \\
B3 & $1.309 \mathrm{E}-05$ & & & \\
\hline
\end{tabular}

